\title{
The transcriptional repressor HIC1 regulates intestinal immune homeostasis
}

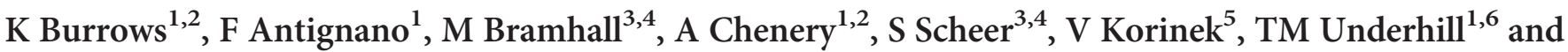 \\ C Zaph ${ }^{1,2,3,4}$
}

The intestine is a unique immune environment that must respond to infectious organisms but remain tolerant to commensal microbes and food antigens. However, the molecular mechanisms that regulate immune cell function in the intestine remain unclear. Here we identify the POK/ZBTB family transcription factor hypermethylated in cancer 1 (HIC1, ZBTB29) as a central component of immunity and inflammation in the intestine. HIC1 is specifically expressed in immune cells in the intestinal lamina propria (LP) in the steady state and mice with a T-cell-specific deletion of HIC1 have reduced numbers of T cells in the LP. HIC1 expression is regulated by the Vitamin A metabolite retinoic acid, as mice raised on a Vitamin A-deficient diet lack HIC1-positive cells in the intestine. HIC1-deficient T cells overproduce IL-17A in vitro and in vivo, and fail to induce intestinal inflammation, identifying a critical role for HIC1 in the regulation of T-cell function in the intestinal microenvironment under both homeostatic and inflammatory conditions.

\section{INTRODUCTION}

The intestinal immune system is constantly interacting with non-pathogenic commensal organisms and innocuous food antigens that must be tolerated immunologically, while simultaneously maintaining the ability to rapidly respond to infectious organisms and toxins. To maintain this balance, unique immune cell populations are found in the intestinal microenvironment. For example, intestinal-resident dendritic cells that express the surface marker CD103 have been shown to affect intestinal homeostasis by producing the vitamin A metabolite retinoic acid (RA). ${ }^{1}$ Intestinal macrophages have also been shown to have a central role in tolerance in the intestine. ${ }^{2,3}$ Specific subsets of $\mathrm{CD} 4^{+} \mathrm{T}$ helper $\left(\mathrm{T}_{\mathrm{H}}\right)$ cells, primarily FOXP3-expressing regulatory $\mathrm{T}$ cells $\left(\mathrm{T}_{\text {reg }}\right.$ cells $)$ and IL-17A-producing $\mathrm{T}_{\mathrm{H}}$ cells $\left(\mathrm{T}_{\mathrm{H}} 17\right.$ cells) are enriched in the intestinal lamina propria (LP), ${ }^{4}$ whereas $\mathrm{CD} 8{ }^{+} \mathrm{T}$ cells and $\gamma \delta \mathrm{T}$ cells are found in the intraepithelial compartment, ${ }^{5}$ acting in conjunction with IgA-producing B cells that are required to maintain tolerance to the commensal flora. ${ }^{6}$ However, the molecular mechanisms that regulate intestinal immune cell function in health and disease are not fully defined.
The POZ and Kruppel/Zinc Finger and BTB (POK/ZBTB) proteins are a family of transcription factors that have critical roles in a variety of biological processes such as gastrulation, limb formation, cell cycle progression, and gamete formation. ${ }^{7}$ In the immune system, POK/ZBTB proteins are key regulators in cellular differentiation and function. ${ }^{8}$ For example, B-cell CLL/Lymphoma 6 (BCL6, ZBTB27) is critical for the development of germinal centers following immunization or infection. BCL6 is expressed at high levels in germinal center $\mathrm{B}$ cells ${ }^{9}$ and $\mathrm{T}$ follicular helper cells ${ }^{10}$ that together control the germinal center response. Promyelocytic leukemia zinc finger (ZBTB16) is required for natural killer T-cell development ${ }^{11}$ and expression of promyelocytic leukemia zinc finger has recently been shown to identify a multipotent progenitor of innate lymphoid cells. ${ }^{12} \mathrm{~T}_{\mathrm{H}}$-inducing POZ/Kruppel-Like factor (ThPOK, ZBTB7B) is a master regulator of $\mathrm{T}_{\mathrm{H}}$-cell development in the thymus. ${ }^{13,14}$ Hypermethylated in cancer 1 (HIC1, ZBTB29) is a member of this family and has been shown to regulate proliferation and p53-dependent survival in a wide range of tumors. HIC1 is epigenetically silenced through DNA methylation in various human cancers ${ }^{15,16}$ and it has been

${ }^{1}$ The Biomedical Research Centre, University of British Columbia, Vancouver, British Columbia, Canada. ${ }^{2}$ Department of Pathology and Laboratory Medicine, University of British Columbia, Vancouver, British Columbia, Canada. Infection and Immunity Program, Monash Biomedicine Discovery Institute, Clayton, Victoria, Australia. ${ }^{4}$ Department of Biochemistry and Molecular Biology, School of Biomedical Sciences, Monash University, Clayton, Victoria, Australia. ${ }^{5}$ Department of Cell and Developmental Biology, Institute of Molecular Genetics, Academy of Sciences of the Czech Republic, Prague, Czech Republic and ${ }^{6}$ Department of Cellular \& Physiological Sciences, University of British Columbia, Vancouver, British Columbia, Canada. Correspondence: C Zaph (colby.zaph@monash.edu) 
proposed that HIC1-dependent repression of SIRT1 was critical for the function of p53. ${ }^{17}$ However, the role of $\mathrm{HIC1}$ in immune cells has not been examined.

In this study, we identify HIC1 as a regulator of intestinal immune responses under homeostatic and inflammatory conditions. We demonstrate that $\mathrm{HIC} 1$ is expressed in immune cells specifically in the intestinal LP but not in other lymphoid or non-lymphoid tissues in the steady state. In the absence of $\mathrm{HIC1}$ in $\mathrm{T}$ cells, we observe a significant reduction in the frequency of $\mathrm{T}$ cells in the LP and intraepithelial compartment, coincident with increased $\mathrm{T}_{\mathrm{H}} 17$-cell responses. HIC1 expression in the LP is regulated by the vitamin A metabolite RA and under inflammatory conditions in the intestine, loss of $\mathrm{HIC1}$ specifically in T cells renders mice resistant to the development of intestinal inflammation, suggesting that $\mathrm{HIC} 1$ is required for the pathogenicity of T cells in vivo. Thus, $\mathrm{HICl}$ has a central role in intestinal immune homeostasis and inflammation.

\section{RESULTS}

\section{HIC1 expression in immune cells is restricted to the intestine}

To begin to address the role of $\mathrm{HIC} 1$ in the immune system, we examined the expression of $\mathrm{HIC} 1$ in $\mathrm{CD}_{4} 5^{+}$leukocytes in various tissues of mice with a fluorescent reporter gene inserted in the Hicl locus ( $\mathrm{Hicl}^{\mathrm{Citrine}}$ mice). ${ }^{18}$ Citrine expression in $\mathrm{CD} 5^{+}$cells was restricted to the intestine, with the only detectable Citrine-positive cells in the LP and intraepithelial space (Figure 1a). Further characterization of the leukocytes in the LP revealed that a majority of T-cell receptor $\beta$ (TCR $\beta)$ chain-expressing $\mathrm{CD}^{+}$and $\mathrm{CD} 8^{+} \mathrm{T}$ cells and $\mathrm{TCR} \gamma \delta^{+}$ $\mathrm{CD}^{+}{ }^{+} \mathrm{T}$ cells in the LP-expressed HIC1 (Figure 1b) and that $\mathrm{TCR} \beta^{+} \mathrm{CD}^{+}$and $\mathrm{TCR} \gamma \delta^{+} \mathrm{CD} 8{ }^{+}$intraepithelial lymphocytes also expressed HIC1 (Figure 1c). We also found that most $\mathrm{MHCII}^{+} \mathrm{CD}_{11 \mathrm{c}^{+}} \mathrm{CD}^{-}$dendritic cells and $\mathrm{MHCII}^{+}$ $\mathrm{CD} 4^{+} \mathrm{F} 4 / 80^{+}$macrophages expressed HIC1 (Supplementary Figure 1 online). However, HIC1 expression was not generalized for all lymphocytes in the $\mathrm{LP}$, as $\mathrm{B}_{22} 20^{+} \mathrm{B}$ cells did not express HIC1 (Figure 1b). Thus, HIC1 expression in immune cells specifically identifies intestinal resident populations.

\section{T cell-intrinsic expression of HIC1 regulates intestinal immune homeostasis}

As $\mathrm{HIC1}$ was expressed in multiple immune cell populations in the LP, we next sought to determine the cell-intrinsic functions of HIC1 by focusing on its role specifically in T cells. To do this, we crossed mice with loxP sites flanking the Hicl gene ( $\mathrm{Hicl}^{\mathrm{fl} / \mathrm{fl}}$ mice) with mice that express the Cre recombinase under control of the $C d 4$ enhancer and promoter ( $C d 4$-Cre mice) to generate mice with a T cell-intrinsic deletion of $\mathrm{Hicl}\left(\mathrm{Hicl}^{\Delta T}\right.$ mice). Hicl ${ }^{\Delta T}$ mice displayed normal thymic development (Supplementary Figure 2a and $\mathbf{b}$ ) and had normal frequencies of $\mathrm{CD}^{+}$and $\mathrm{CD} 8^{+} \mathrm{T}$ cells in the spleen (Supplementary Figure 2c) or mesenteric lymph nodes (Supplementary Figure 2d). HIC1 also had no effect on the activation state
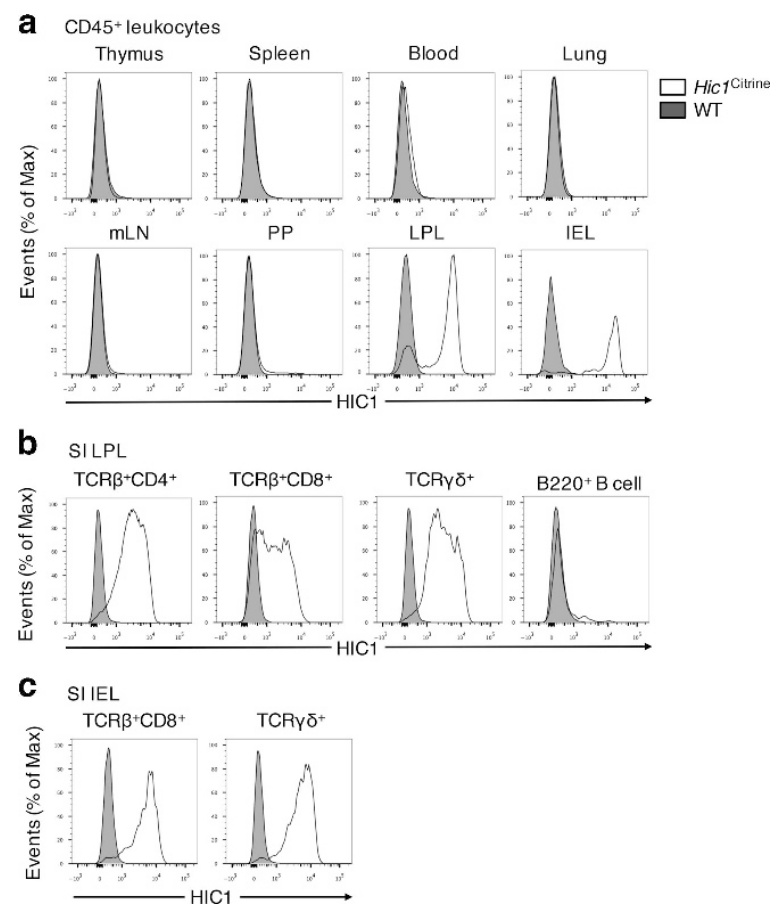

Figure $1 \mathrm{HIC} 1$ expression in immune cells is restricted to the intestine. (a) Steady state thymus, spleen, blood, lung, mesenteric lymph node $(\mathrm{mLN})$, peyer's patch (PP) and intestinal lamina propria (LPL), and intraepithelial leukocytes (IEL) were analyzed by flow cytometry for Hic1 ${ }^{\text {Citrine }}$ reporter expression in total CD45 ${ }^{+}$leukocytes. (b) TCR $\beta^{+}$ $\mathrm{CD}^{+}{ }^{+} \mathrm{T}$ cells, $\mathrm{TCR} \beta^{+} \mathrm{CD}^{+}{ }^{+} \mathrm{T}$ cells, $\mathrm{TCR} \gamma \delta^{+}{ }^{+} \mathrm{T}$ cells, or $\mathrm{B} 220^{+} \mathrm{B}$ cells were analyzed by flow cytometry for Hic $1^{\text {Citrine }}$ reporter expression from the intestinal lamina propria or (c) intraepithelial compartment. (a-c) Data are representative of three independent experiments.

of splenic $\mathrm{CD} 4^{+} \mathrm{T}$ cells, as we observed equivalent expression of $\mathrm{CD} 62 \mathrm{~L}$ and $\mathrm{CD} 44$ between $\mathrm{Hicl} \mathrm{f}^{\mathrm{flf}}$ and $\mathrm{Hicl}^{\Delta T}$ mice (Supplementary Figure 2e). Finally, HIC1 was not required for the development of FOXP3 ${ }^{+} \mathrm{CD} 25^{+} \mathrm{CD} 4{ }^{+} \mathrm{T}$ cells in the spleen or mLNs (Supplementary Figure 2f). Thus, HIC1 expression is dispensable for peripheral T-cell homeostasis. However, we found that the frequency and number of $\mathrm{CD} 44^{+}$ and $\mathrm{CD} 8{ }^{+} \mathrm{TCR}^{+}$cells in the LP (Figures $2 \mathbf{a}$ and $\mathbf{b}$ ) and $\mathrm{CD}^{+} \mathrm{T}$ cells in the intraepithelial compartment (Figures 2a and b) were significantly reduced in the absence of $\mathrm{HICl}$, demonstrating that $\mathrm{T}$ cell-intrinsic expression of $\mathrm{HICl}$ is required for intestinal $\mathrm{T}$-cell homeostasis.

Lamina propria lymphocytes (LPLs) and intraepithelial lymphocytes display an activated, memory phenotype that includes the markers CD69 and CD103, cell surface molecules that are important for retention in the intestinal microenvironment. CD69 has been shown to negatively regulate expression of sphingosine-1-phosphate receptor, which must be downregulated to establish tissue-residency, ${ }^{19,20}$ whereas CD103 binds to the epithelial cell-expressed E-cadherin and is required for maintenance of intestinal T cells. ${ }^{21}$ We found that HIC1-deficient $\mathrm{CD}^{+}{ }^{+}$and $\mathrm{CD} 8{ }^{+}{ }^{+}$cells in the $\mathrm{LP}$ and intraepithelial compartments expressed significantly reduced levels of CD69 and CD103 (Figures $2 \mathbf{c}$ and d). Strikingly, there was an almost complete loss of $\mathrm{CD} 103^{+} \mathrm{CD} 69^{+} \mathrm{CD} 4{ }^{+} \mathrm{T}$ cells 


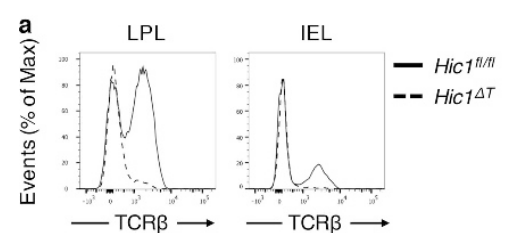

c

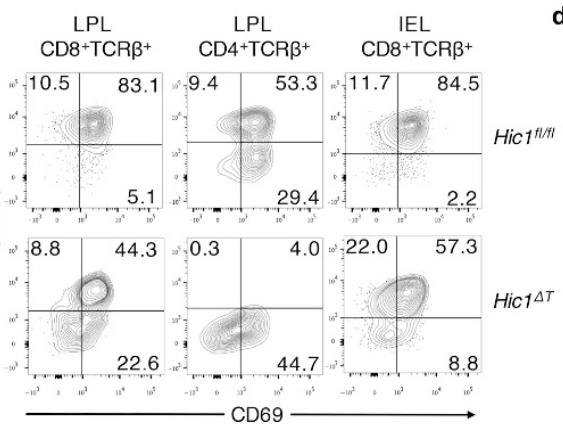

b
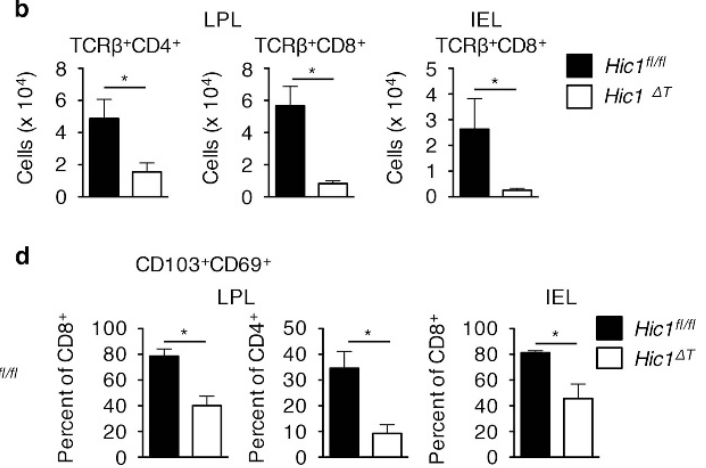

Figure 2 T cell-intrinsic expression of HIC1 regulates intestinal T-cell homeostasis. Intestinal lamina propria (LPL) and intraepithelial (IEL) lymphocytes were isolated from $\mathrm{Hic} 1^{\mathrm{fl} / f l}$ or Hic $1^{\Delta T}$ mice. (a) Frequency of TCR $\beta^{+}$T cells and (b) total number of TCR $\beta^{+} \mathrm{CD} 4^{+}$and TCR $\beta^{+} \mathrm{CD}{ }^{+} \mathrm{T} \mathrm{cells} \mathrm{were} \mathrm{analyzed}$ by flow cytometry. (c) Flow cytometry analysis and (d) quantification of CD103 and CD69 surface marker expression from IEL and LPL TCR $\beta^{+}$CD $4^{+}$and $\mathrm{TCR}^{+} \mathrm{CD}^{+}{ }^{+} \mathrm{T}$ cells. (a,c) Data are representative of three independent experiments. (b,d) Data are pooled from three independent experiments ( $n=6-7$ per group). ${ }^{\star} P<0.05$. Error bars indicate s.e.m.

a $\mathrm{LPLCD} 4+\mathrm{TCR} \beta^{+}$
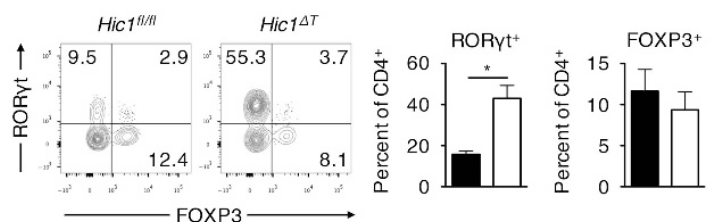

b $\mathrm{LPLCD} 4{ }^{+} \mathrm{TCR} \beta^{+}$
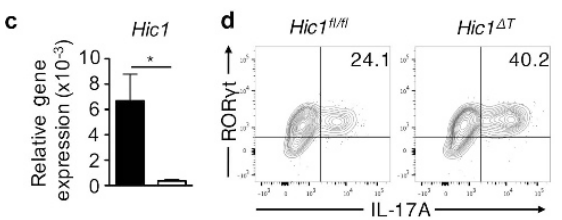

e

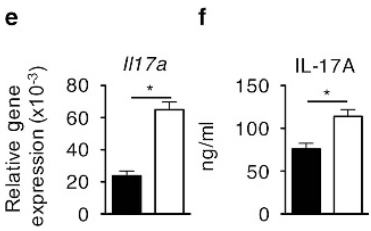

g

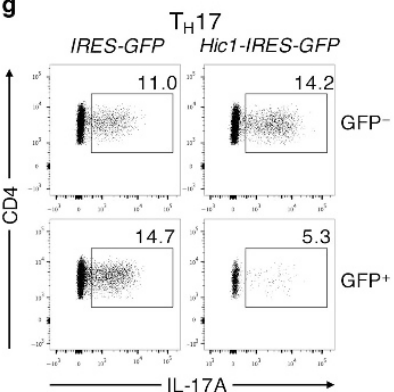

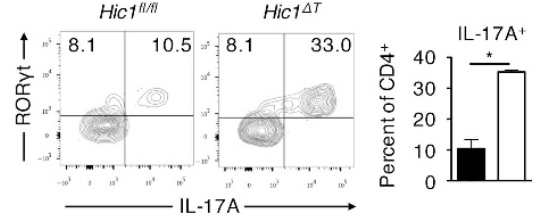

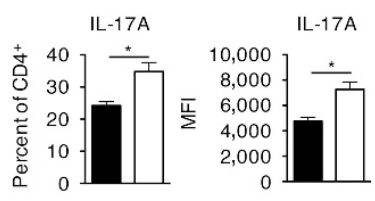

h

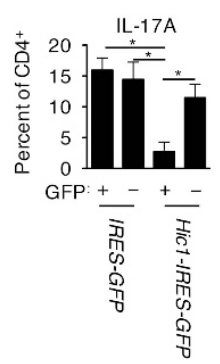

Figure $3 \mathrm{HIC1}$ is a negative regulator of IL-17A production by CD4 ${ }^{+}$T cells. (a,b) Steady-state intestinal lamina propria (LPL) CD4 ${ }^{+}$T cells were isolated from $\mathrm{Hic} 1^{\mathrm{fl} / f l}$ or Hic $1^{\Delta T}$ mice and analyzed by flow cytometry for intracellular expression of ROR $\gamma \mathrm{t}$, FOXP3, and IL-17A. Data are pooled from three

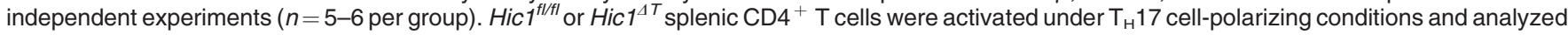
for: (c) Hic1 mRNA expression by quantitative RT-PCR, (d) intracellular ROR $\gamma$ t and IL-17A frequency and mean fluorescence intensity (MFI) by flow cytometry, (e) IL-17A protein production by ELISA, and (f) I/17a mRNA expression by qRT-PCR. Data are pooled from four independent experiments ( $n=4-8$ per group). (g,h) Analysis of IL-17A expression from $\mathrm{T}_{\mathrm{H}} 17$ cells that were retrovirally transduced with MigR1-IRES GFP (empty vector) or MigR1Hic1-IRES GFP expression vectors. GFP ${ }^{+}$indicated successful retroviral infection. (h) Data are pooled from three independent experiments $(n=3$ per group). ${ }^{\star} P<0.05$. Error bars indicate s.e.m.

in the LP (Figures $2 \mathrm{c}$ and $\mathbf{d}$ ). Thus, the reduced frequency and number of $\mathrm{CD}^{+}$and $\mathrm{CD}^{+}$LPLs and intraepithelial lymphocytes in $\mathrm{Hicl}^{\Delta T}$ mice is associated with reduced expression of CD69 and CD103.

\section{HIC1 is a negative regulator of IL-17A production by CD4 ${ }^{+}$ $T$ cells}

In the intestinal LP, CD4 ${ }^{+} \mathrm{T}_{\mathrm{H}} 17$ and $\mathrm{T}_{\text {reg }}$ cells are found at higher frequencies than other $\mathrm{T}_{\mathrm{H}^{-}}$-cell subsets. Analysis of the 

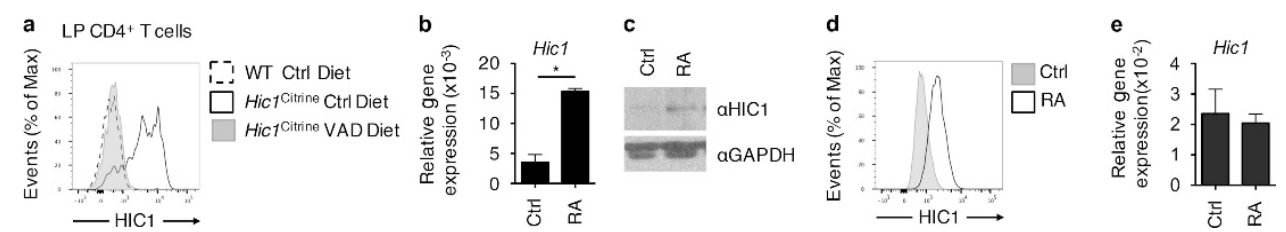

Figure 4 Retinoic acid regulates expression of $\mathrm{HIC} 1$ in $\mathrm{CD} 4^{+} \mathrm{T}$ cells. (a) $\mathrm{HIC} 1$ reporter expression in intestinal lamina propria (LP) $\mathrm{CD} 4{ }^{+} \mathrm{T}$ cells from Hic ${ }^{\text {Citrine }}$ mice fed a control diet, Hic ${ }^{\text {Citrine }}$ mice fed a vitamin A-deficient (VAD) diet, and controls fed a control diet was analyzed by flow cytometry. Data are representative of three independent experiments. (b-d) Splenic $T_{H}$ cells were activated with antibodies against CD3 and CD28 in the presence or absence of $10 \mathrm{~nm}$ RA and HIC1 levels were measured by (b) quantitative RT-PCR (c) western blot and (d) HIC1 reporter expression. (b) Data are pooled from two independent experiments ( $n=4$ per group). (c,d) Data are representative of two independent experiments. (e) Expression of Hic1 in naive splenic CD4 ${ }^{+}$T cells that were treated with $10 \mathrm{~nm}$ RA for $16 \mathrm{~h}$ was analyzed by qRT-PCR. Data are pooled from two independent experiments $(n=4$ per group). ${ }^{*} P<0.05$. Error bars indicate s.e.m.

a

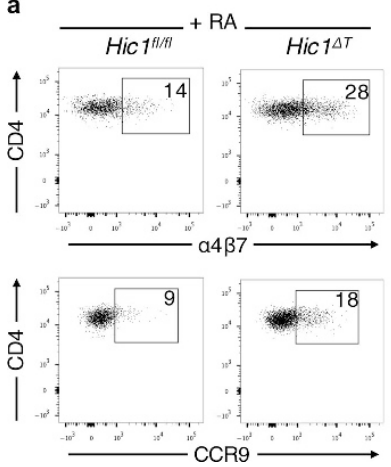

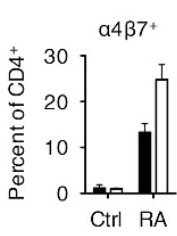

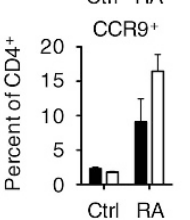

b

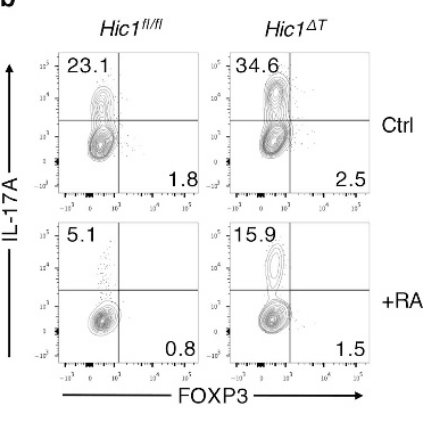

Figure 5 HIC1 is not required for all RA-mediated effects on CD4 ${ }^{+}$T cells. (a) Splenic $\mathrm{T}_{\mathrm{H}}$ cells were activated with antibodies against CD3 and CD28 in the presence of $10 \mathrm{~nm} \mathrm{RA;} \alpha 4 \beta 7^{+}$and CCR9 levels were measured by flow cytometry and quantitative RT-PCR. Data are pooled from two independent experiments ( $n=4$ per group). (b) Splenic CD4 ${ }^{+}$T cells were activated under $\mathrm{T}_{H} 17$ cell-polarizing conditions in the presence or absence of $10 \mathrm{~nm}$ RA and analyzed for intracellular IL-17A and FOXP3 by flow cytometry. Data are representative of three independent experiments. ${ }^{\star} P<0.05$. Error bars indicate s.e.m.

$\mathrm{CD} 4{ }^{+}$LPLs showed that although frequency of FOXP3 ${ }^{+} \mathrm{T}_{\text {reg }}$ cells were equivalent between $\mathrm{Hicl}^{\mathrm{fl} / \mathrm{fl}}$ and $\mathrm{Hicl}^{\Delta T}$ mice, the frequency of $\mathrm{ROR}_{\gamma \mathrm{t}}{ }^{+}$IL-17A-expressing $\mathrm{T}_{\mathrm{H}} 17$ cells in $\mathrm{Hicl}^{\Delta T}$ mice was significantly increased (Figures $3 \mathbf{a}$ and $\mathbf{b}$ ). Further, splenic T cells in Hic ${ }^{\Delta T}$ mice displayed a small but significant increase in the frequency of IL-17A expression $\mathrm{T}_{\mathrm{H}} 17$ cells (Supplementary Figure 3). These results suggest that in addition to regulating T-cell numbers in the intestine, HIC1 deficiency in $\mathrm{T}$ cells had a specific effect on $\mathrm{T}_{\mathrm{H}} 17$-cell differentiation. To directly examine the role of $\mathrm{HICl}$ in $\mathrm{T}_{\mathrm{H}^{-}}$ cell differentiation, we stimulated $\mathrm{T}_{\mathrm{H}}$ cells that were purified from the spleen and peripheral lymph nodes of naive Hicl ${ }^{f l f l}$ and $\mathrm{Hicl}^{\Delta T}$ mice (Figure 3c) under diverse polarizing conditions. HIC1 deficiency had no effect on the development of $\mathrm{T}_{\mathrm{H}} 1, \mathrm{~T}_{\mathrm{H}} 2$, or tumor growth factor (TGF)- $\beta$ induced $\mathrm{T}_{\text {reg }}$ cells (Supplementary Figure 4). Consistent with our in vivo results, we observed a significant increase in the production of IL-17A by HIC1-deficient $\mathrm{T}_{\mathrm{H}}$ cells activated under $\mathrm{T}_{\mathrm{H}} 17$ cell-promoting conditions, with heightened frequency and mean fluorescence intensity of IL-17A ${ }^{+}$cells (Figure 3d), resulting in a significant increase in the levels of secreted IL-17A (Figure 3e), which was also associated with increased Il17a expression in HIC1-deficient $\mathrm{T}_{\mathrm{H}} 17$ cells (Figure 3f). Retroviral transduction of $\mathrm{HIC1}$ into differentiating $\mathrm{T}_{\mathrm{H}} 17$ cells resulted in a complete inhibition of IL-17A production (Figures $\mathbf{3 g}$ and $\mathbf{h}$ ). Taken together, these results suggest that $\mathrm{HIC1}$ is a cell-intrinsic negative regulator of IL-17A production during $\mathrm{T}_{\mathrm{H}} 17$-cell differentiation.

\section{RA regulates expression of $\mathrm{HIC1}$ in $\mathrm{T}$ cells in vitro and in vivo}

The vitamin A metabolite RA has a critical role in intestinal immune homeostasis. ${ }^{22}$ Previous studies have shown that mice raised on a diet lacking vitamin $\mathrm{A}$ (VAD diet) have defects in $\mathrm{T}_{\mathrm{H}}$-cell activation and intestinal migration, resulting in an overall impairment in T-cell-driven immune responses in the intestine. ${ }^{23-25}$ To test whether RA influenced HIC1 expression in intestinal $\mathrm{T}_{\mathrm{H}}$ cells, we raised $\mathrm{Hicl}^{\text {Citrine }}$ mice on a VAD diet. We found that $\mathrm{LP}_{\mathrm{H}}$ cells from VAD mice failed to express $\mathrm{HIC1}$ (Figure 4a), suggesting that $\mathrm{HIC1}$ expression in $\mathrm{T}_{\mathrm{H}}$ cells in the LP is dependent on the presence of RA. Consistent with this, addition of RA to $\mathrm{T}_{\mathrm{H}}$ cells isolated from spleen or lymph nodes of mice activated in vitro with antibodies against $\mathrm{CD} 3$ and $\mathrm{CD} 28$ resulted in an upregulation of $\mathrm{HICl}$ at the mRNA and protein levels (Figures $\mathbf{4 b}$ and $\mathbf{c}$ ). Analysis of $\mathrm{HIC1}$ expression using Hicl ${ }^{\text {Citrine }}$ mice further demonstrated that treatment of activated $\mathrm{T}_{\mathrm{H}}$ with RA led to increased HIC1 expression (Figure 4d). Expression of HIC1 was dependent upon $\mathrm{T}_{\mathrm{H}}$-cell activation, as addition of RA to $\mathrm{T}_{\mathrm{H}}$ cells in the absence of 
TCR stimulation had no effect on the expression of Hicl mRNA (Figure 4e). Thus, these results identify $\mathrm{HICl}$ as an RA-responsive gene in activated $\mathrm{T}_{\mathrm{H}}$ cells.

\section{HIC1 is dispensable for expression of intestinal homing receptors}

RA is critical for migration of immune cells to the intestine ${ }^{24}$ through the upregulation of intestinal homing molecules, including $\alpha 4 \beta 7$ integrin and CCR9. ${ }^{25}$ Our results showing that $H_{i c 1}{ }^{\Delta T}$ mice had reduced numbers of intestinal $\mathrm{T}$ cells could be owing to reduced expression of intestinal homing molecules, resulting in impaired intestinal migration. However, we failed to observe any reduction in expression of $\alpha 4 \beta 7$ and CCR 9 on $\mathrm{T}_{\mathrm{H}}$ cells in the presence or absence of HIC1 following activation in the presence of RA (Figure 5a). Further, we found that $T_{H}$ cells isolated from the Peyer's patches or mLNs of $\mathrm{Hicl}^{\Delta T}$ mice were not deficient in expression of CCR9 (Supplementary Figure 5). These results demonstrate that other HIC1-dependent mechanisms such as reduced expression of CD69 and CD103 were responsible for the paucity of $\mathrm{T}_{\mathrm{H}}$ cells in the $\mathrm{LP}$ and that HICl is dispensable for RA-dependent induction of intestinal homing molecules.

\section{HIC1 is not required for inhibitory effects of RA on $T_{H}$ 17-cell differentiation}

Several studies have demonstrated that RA can negatively affect the differentiation of $\mathrm{T}_{\mathrm{H}} 17$ cells $^{26-29}$ although the precise mechanisms remain unclear. Based on our data showing heightened IL-17A production by HIC1-deficeint $\mathrm{T}_{\mathrm{H}} 17$ cells in vitro and in vivo, we hypothesized that expression of HIC1 would be required for the RA-dependent reduction in $\mathrm{T}_{\mathrm{H}} 17$-cell differentiation. In contrast to our expectations, addition of RA to either HIC1-sufficient or -deficient $\mathrm{T}_{\mathrm{H}}$ cells led to a significant reduction in the expression of IL-17A (Figure 5b). Thus, although HIC1 is upregulated by RA in $\mathrm{T}_{\mathrm{H}}$ cells and HIC1-deficient $\mathrm{T}_{\mathrm{H}} 17$ cells express increased levels of IL-17A in vitro and in vivo, $\mathrm{HICl}$ is dispensable for RA-dependent regulation of $\mathrm{T}_{\mathrm{H}} 17$ cell responses in vitro.

\section{HIC1 regulates $T$ cell-mediated inflammation in the intestine}

We next examined whether dysregulated $\mathrm{T}_{\mathrm{H}}$-cell responses observed in naive $\mathrm{Hicl}^{\Delta T}$ mice had any effect on the development of intestinal inflammation. Despite the reduced numbers of $\mathrm{T}_{\mathrm{H}}$ cells in the LP of $\mathrm{Hicl}^{\Delta T}$ mice and the dysregulated production of IL-17A by $\mathrm{HIC1}$-deficient $\mathrm{T}_{\mathrm{H}} 17$ cells, we failed to observe any significant differences in intestinal architecture between naive $\mathrm{Hic}^{f l / f l}$ or $\mathrm{Hicl}^{\Delta T}$ mice (Figure 6a, left panels). After induction of intestinal inflammation with intraperitoneal injection of a monoclonal antibody against $\mathrm{CD} 3,{ }^{30-32} \mathrm{Hicl}^{\Delta T}$ mice displayed less intestinal inflammation compared with control Hic ${ }^{f l f l}$ mice (Figures 6a and $\mathbf{b}$ ). Although we observed fewer $\mathrm{CD}^{+}{ }^{+} \mathrm{T}$ cells in the intestine of treated $\mathrm{Hicl}^{\Delta T}$ mice (Figure 6c), we did observe an increase in the number of $\mathrm{CD} 4^{+}$ $\mathrm{T}$ cells in the LP of treated $\mathrm{Hicl}^{\Delta T}$ mice compared with naive $\mathrm{HiCl}^{\Delta T}$ mice (Figures $\mathbf{2 a}$ and $\mathbf{b}$ ), further demonstrating that intestinal migration is not completely impaired in the absence of $\mathrm{HIC1}$. Analysis of cytokine production by $\mathrm{T}_{\mathrm{H}}$ cells from the LP a
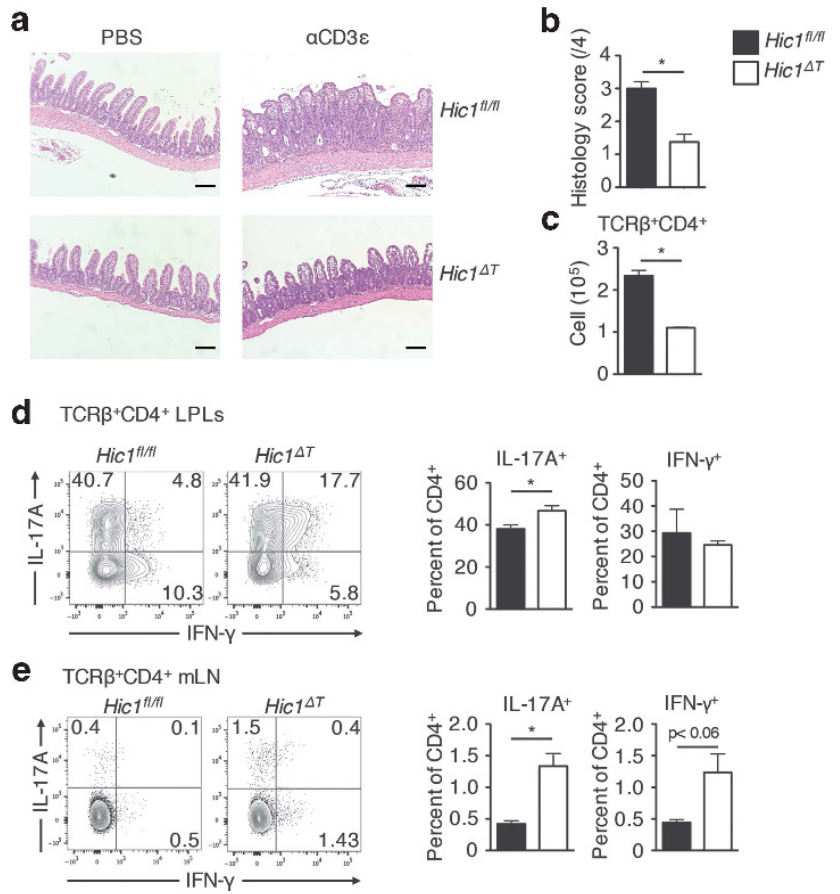

Figure $6 \mathrm{HIC} 1$ is required for the development of intestinal inflammation. Mice received anti-CD3 $\varepsilon$ antibody by intraperitoneal injection. (a) At $48 \mathrm{~h}$ post injection, mice were killed and analyzed for intestinal tissue pathology and inflammatory infiltrate by H\&E staining. Scale bar represents $100 \mu \mathrm{m}$. (b) Histological scores. (c) Total numbers of intestinal lamina propria (LPL) TCR $\beta^{+} \mathrm{CD} 4^{+} \mathrm{T}$ cells were quantified by flow cytometry. (d,e) Intracellular expression of IL-17A and IFN- $\gamma$ from (d) LPL and (e) mLN CD4 ${ }^{+}$T cells were analyzed by flow cytometry. (a-e) Data are from three independent experiments ( $n=8-9$ per group). ${ }^{\star} P<0.05$. Error bars indicate s.e.m.

and $\mathrm{mLN}$ of anti-CD3-treated mice identified an increased frequency of IL-17A-producing $\mathrm{T}_{\mathrm{H}}$ cells without any changes in the frequency of IFN- $\gamma$-producing cells (Figures $\mathbf{6 c}$ and $\mathbf{d}$ ), similar to our results under steady-state conditions. Thus, T cellintrinsic expression of HIC1 modulates inflammation in the intestine, potentially by negatively regulating IL-17A production.

To directly assess the cell-intrinsic role of $\mathrm{HICl}$ in intestinal inflammation, we employed a T-cell transfer model of intestinal inflammation. ${ }^{33}$ We adoptively transferred naive $\mathrm{CD} 4^{+}$ $\mathrm{CD} 25^{-} \mathrm{CD}^{2} 5 \mathrm{RB}^{\text {high }} \mathrm{T}$ cells isolated from either Hic $\mathrm{f}^{\text {fl/fl }}$ or $\mathrm{Hicl}^{\Delta T}$ mice into Rag1 ${ }^{-1-}$ mice. Rag1 ${ }^{-1-}$ mice that received control T cells from $\mathrm{Hicl}^{\text {flflf }}$ mice began losing weight $\sim 4$ weeks post transfer (Figure 7a) and showed significant intestinal inflammation by 6 weeks post transfer (Figure 7 b). Strikingly, we found that $\mathrm{Rag}^{-1-}$ mice that received T cells from Hicl ${ }^{4 T}$ mice continued to gain weight and did not develop severe intestinal inflammation (Figures $7 \mathbf{a}-\mathbf{c}$ ). Associated with the reduced disease, there were significantly fewer $\mathrm{CD} 4{ }^{+} \mathrm{T}$ cells in the intestinal LP (Figure 7d). Furthermore, consistent with our results under homeostatic conditions as well as following $\alpha$-CD3 treatment, we found that the absence of HIC1 in T cells resulted in heightened production of IL-17A in the LP and spleen with no significant effect on the frequency of IFN- $\gamma$ positive cells (Figures $7 \mathbf{e}$ and $\mathbf{f}$ ). Thus, HIC1 expression in $\mathrm{T}$ cells is critically required for the development of intestinal inflammation, possibly by limiting expression of IL-17A. 
a

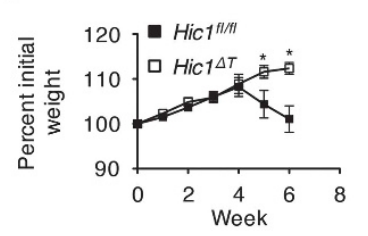

b

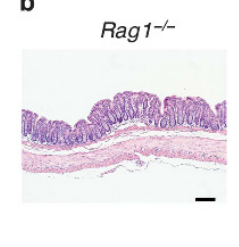

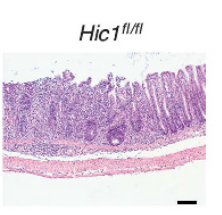
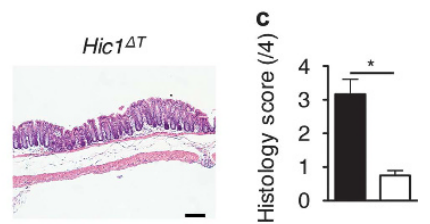

d

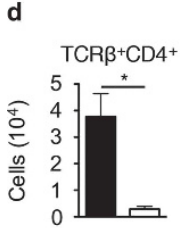

e $\mathrm{TCR} \beta{ }^{+} \mathrm{CD} 4+\mathrm{LPLs}$
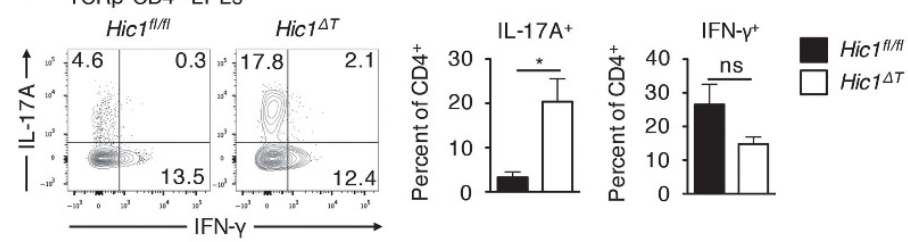

f
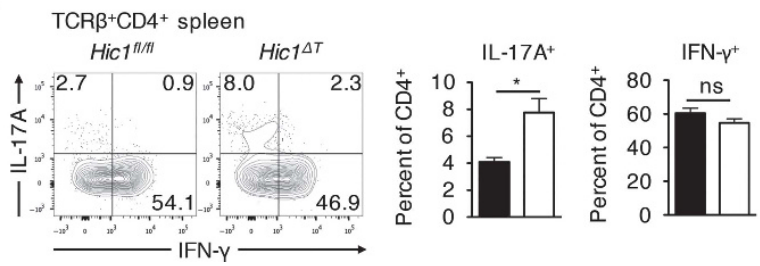

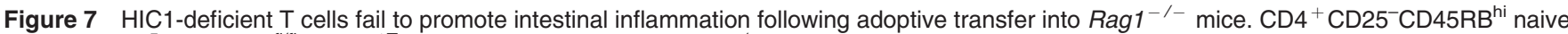
T cells $\left(4 \times 10^{5}\right)$ from Hic $1^{\text {fl/fl }}$ or Hic $1^{\Delta T}$ mice were transferred into Rag $1^{-1-}$ mice and monitored for colitis. (a) Weight loss (percentage of initial weight) was calculated for each mouse over 6 weeks. (b) At 6 weeks post transfer, mice were killed and analyzed for intestinal tissue pathology and inflammatory infiltrate by H\&E staining. Scale bar represents $100 \mu \mathrm{m}$. (c) Histological scores. (d) Total number of TCR $\beta^{+}$CD4 ${ }^{+} \mathrm{T}$ cells isolated from intestinal lamina propria (LPL). (e,f) Intracellular expression of IL-17A and IFN- $\gamma$ from (e) LPL and (f) Spleen CD4 ${ }^{+}$T cells were analyzed by flow cytometry. (a-f) Data are pooled two of four independent experiments ( $n=4-8$ per experiment). Statistics compare $R$ ag $1^{-/-}$mice that received Hic $1^{f l / f l} \mathrm{~T}$ cells to those that received Hic $1^{\Delta T}$ T cells. ${ }^{*} P<0.05$. Error bars indicate s.e.m. ns; not significant.

Finally, to determine whether HIC1-deficient T cells have a protective role in a non-T-cell driven model of intestinal inflammation, we employed dextran sodium sulfate (DSS)induced colitis. This model involves chemically induced epithelial cell damage, which leads to bacterial translocation and activation of sub-epithelial innate immune cells and therefore does not require $\mathrm{T}$ or $\mathrm{B}$ cells for development of disease. ${ }^{34,35} \mathrm{Hicl}^{f l f l}$ mice and Hicl ${ }^{\Delta T}$ mice were exposed to $3.5 \%$ DSS in their drinking water for 7 days before returning to regular drinking water for one final day. DSS-treated Hicl ${ }^{\Delta T}$ mice exhibited attenuated weight loss in comparison with treated $\mathrm{Hicl}^{f l / f l}$ mice (Supplementary Figure 6a). At day 8 after DSS treatment, sections from the colon of DSS-treated $\mathrm{Hicl}^{\Delta T}$ mice revealed negligible damage to the epithelium and a minimal presence of inflammatory cells. In contrast, tissue sections from DSS-treated Hic $1^{f / f l}$ mice exhibited severe mucosal inflammatory cell infiltrate, sloughing of epithelial cells, and complete loss of crypt architecture (Supplementary Figure $\mathbf{6 b}$ and $\mathbf{c}$ ). Therefore, HIC1-deficient $\mathrm{T}$ cells offer a protective function in the development of innate immune cell driven intestinal inflammation.

\section{HIC1 is required to limit STAT3 signaling in $T_{H} 17$ cells}

In addition to directly repressing target genes, $\mathrm{HIC} 1$ has been shown to negatively regulate gene expression by several mechanisms including the recruitment of co-repressors such as the $\mathrm{CtBP}, \mathrm{NuRD}$, and polycomb repressive complex 2 complexes to target genes to mediate gene repression. ${ }^{36,37}$
Further, HIC1 has also been shown to indirectly repress transcription by binding to transcriptional activators and preventing binding to target genes. $\mathrm{HIC1}$ has been shown to interact with and inhibit DNA binding of transcription factors such as T-cell factor- $4, \beta$-catenin, and STAT3 ${ }^{38-40}$ As HIC1deficient $\mathrm{T}_{\mathrm{H}} 17$ cells produce heightened levels of the STAT3 target gene IL-17A, ${ }^{41}$ we hypothesized that increased STAT3 activity was associated with HIC1 deficiency. We first examined the levels of IL-6-induced active phosphorylated STAT3 in $\mathrm{HIC1}$-sufficient and -deficient $\mathrm{T}_{\mathrm{H}} 17$ cells by flow cytometry. We found that loss of HIC1 had no effect on the frequency of phosphorylated STAT3-positive $\mathrm{T}_{\mathrm{H}}$ cells (Figure 8a), suggesting that HIC1 did not affect upstream STAT3 activation. However, co-immunoprecipitation studies in $\mathrm{T}_{\mathrm{H}} 17$ cells of either native HIC1 (Figure 8b) or retrovirally transduced FLAG-tagged HIC1 (Figure 8c) demonstrated that $\mathrm{HIC1}$ and STAT3 interacted in $\mathrm{T}_{\mathrm{H}} 17$ cells. Thus, our results suggest that $\mathrm{HIC} 1$ limits $\mathrm{T}_{\mathrm{H}} 17$-cell differentiation by binding to STAT3, inhibiting its DNA binding and transcriptional activation. Consistent with this hypothesis, we found increased STAT3 binding to the Ill7a promoter in the absence of $\mathrm{HICl}$ (Figure 8d), whereas there was no difference in binding at an irrelevant site (Il5 promoter). Examination of mRNA expression for other known STAT3 target genes associated with TH17-cell differentiation ${ }^{41}$ revealed slight but insignificant increases in gene expression of Rorc, Socs3, Irf4, Ahr, or Il23r (Figure 8e). Thus, HIC1 does not appear to directly regulate the molecular machinery that 

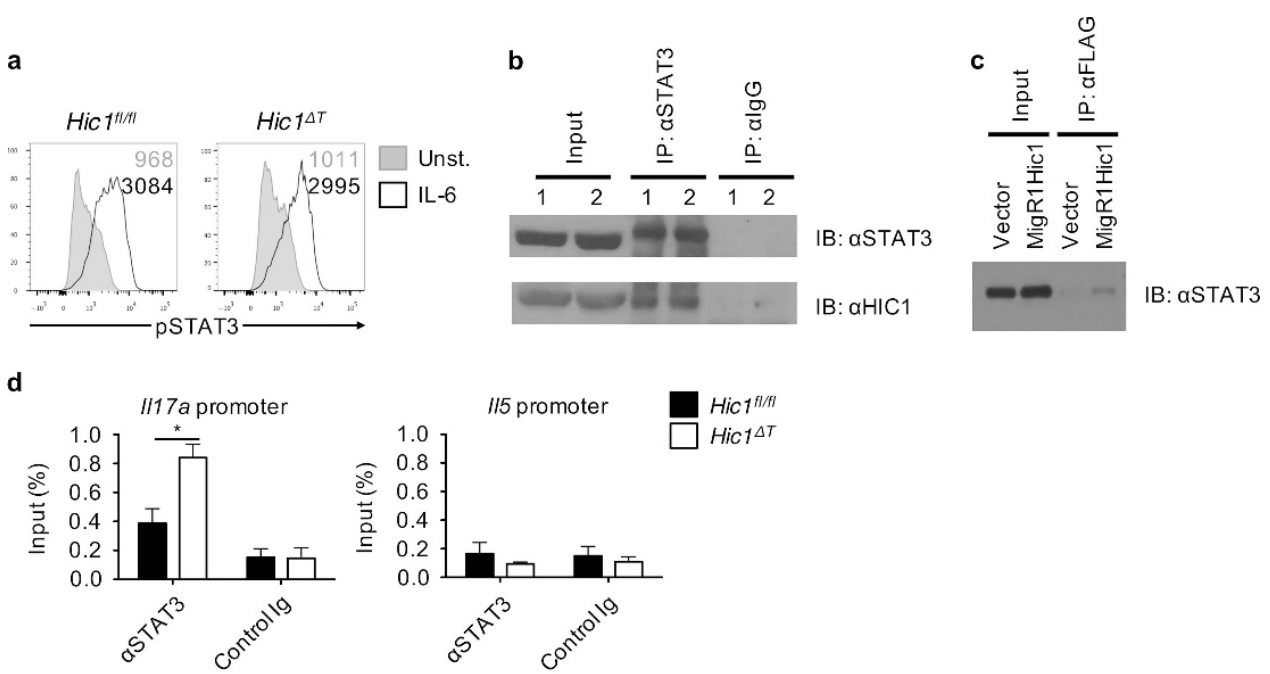

Hict H/H $^{\text {H }}$ Hic1 ${ }^{\Delta T}$

e
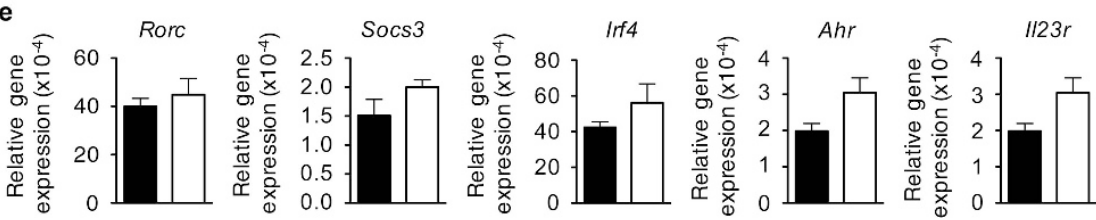

Figure 8 HIC1 regulates STAT3 signaling in $\mathrm{T}_{H} 17$ cells. CD4 ${ }^{+} \mathrm{T}$ cells were activated under $\mathrm{T}_{\mathrm{H}} 17$ cell-polarizing conditions. (a) Flow cytometric analysis of STAT3 phosphorylation from $T_{H} 17$ cells restimulated with or without IL-6 for 15 min. Numbers represent mean fluorescence intensity. Data are representative of two independent experiments. (b) Inputs, anti-STAT3 immunoprecipitates (IP), and normal rat serum IP from $\mathrm{T}_{H} 17$ cells were immunoblotted with anti-STAT3 and anti-HIC1 antibodies. 1 and 2 represent duplicate $\mathrm{T}_{\mathrm{H}} 17$ cultures. Data are representative of two independent experiments. (c) Inputs and anti-FLAG IP from $\mathrm{T}_{\mathrm{H}} 17$ cells retrovirally transduced with MigR1 (empty) or MigR1 FLAG-HIC1 vectors were immunoblotted with an anti-STAT3 antibody. Data are representative of two independent experiments. (d) Chromatin Immunoprecipitation (ChIP) analysis of STAT3 binding to the $/ 117 \mathrm{a}$ and $/ 15$ promoters in $\mathrm{T}_{\mathrm{H}} 17$ cells. Data are from three independent experiments ( $n=6$ per group). (e) Analysis of Rorc, Socs 3 , Irf4, Ahr, II23r mRNA expression by quantitative RT-PCR. Data are from two independent experiments ( $n=6$ per group). ${ }^{*} P<0.05$. Error bars indicate s.e.m.

controls $\mathrm{T}_{\mathrm{H}} 17$-cell differentiation. Instead, our results identify an important role for HIC1 in limiting expression of IL-17A in $\mathrm{T}_{\mathrm{H}} 17$ cells by inhibition of STAT3 DNA binding.

\section{DISCUSSION}

We have identified the transcriptional factor HIC1 as a novel regulator of intestinal immune homeostasis. In the steady state, HIC1 is specifically expressed in immune cells of the intestinal LP and intraepithelial niches in an RA-dependent manner, and mice with a T cell-intrinsic deletion of HIC1 have a marked decrease in the number of T cells in intestinal tissues. HIC1 deficiency leads to increased expression of IL-17A, possibly through the loss of STAT3 inhibition. Under inflammatory conditions, $\mathrm{HICl}$ expression in $\mathrm{T}$ cells is required for intestinal pathology, identifying $\mathrm{HICl}$ as a potential therapeutic target to treat intestinal inflammation.

Our results suggest that the micronutrient RA regulates $\mathrm{HIC1}$ expression in immune cells in the intestine. In support of this, two unrelated genome-wide expression screens for genes in $\mathrm{T}_{\mathrm{H}}$ cells regulated by RA signaling have identified $\mathrm{HIC} 1$ as an RA/RAR $\alpha$-dependent gene, although no functional analyses were carried out. ${ }^{22,42}$ These results are consistent with an in silico study showing that the Hicl gene contains multiple RA receptor response elements. ${ }^{43}$ However, HIC1 is dispensable for RA-mediated expression of intestinal homing molecules and RA-dependent suppression of IL-17A production in vitro, suggesting that the RA-HIC1 axis has a specific role in regulating intestinal T-cell homeostasis that remains to be defined.

$\mathrm{T}$ cell-intrinsic deletion of HIC1 resulted in a significant reduction in the frequency and number of $\mathrm{T}$ cells in the intestinal microenvironment. Interestingly, mice raised on a VAD diet also display reduced numbers of intestinal T cells. ${ }^{24}$ As RA has been shown to regulate expression of intestinal homing molecules such as CCR9 and $\alpha 4 \beta 7$ integrin, we first suspected that defective trafficking to the intestine was responsible for the paucity of $\mathrm{T}$ cells in the intestines of $H i c 1^{\Delta T}$ mice; however, we did not observe any defects in the ability of HIC1-deficient T cells to express CCR9 or $\alpha 4 \beta 7$. In addition, we observed a significant influx of $\mathrm{T}$ cells into intestinal tissues upon induction of inflammation, further suggesting that migration to the intestine is not regulated by expression of HIC1. However, we did observe that the HIC1deficient $\mathrm{T}$ cells present in the intestine at steady state expressed significantly lower levels of the surface molecules CD69 and CD103. These molecules are expressed by tissue-resident cells and are required for retention in tissues. Indeed, similar to our results, CD103-deficient mice have a severe reduction in the number of T cells in the intestine. ${ }^{21}$ Thus, HIC1 appears to be required for the optimal expression of CD69 and CD103 and retention of $\mathrm{T}$ cells in the intestinal microenvironment.

In addition, CD69 and CD103 are characteristic markers of a subset of memory $\mathrm{T}$ cells known as tissue resident memory $\mathrm{T}$ 
cells. Tissue resident memory $\mathrm{T}$ cells are long-lived quiescent cells that are thought to have derived from effector $\mathrm{T}$ cells that have migrated into non-lymphoid tissues. Interestingly, HIC1 has been shown to control fundamental cellular processes such as cell growth and survival. ${ }^{44,45} \mathrm{HIC1}$ has been shown to interact with and regulate key transcription factors involved in cell cycle progression and cellular metabolism. ${ }^{37,46}$ For example, HICl is involved in a regulatory feed back loop with the deacteylase SIRT $1,{ }^{17}$ which is a key regulator of fattyacid oxidation. ${ }^{47}$ Further, it has been demonstrated that fattyacid metabolism is key to memory T-cell development and survival. ${ }^{48,49}$ Thus, it is possible that in addition to directly regulating $\mathrm{T}$-cell retention in tissues, $\mathrm{HICl}$ may also be required in $\mathrm{T}$ cells to promote quiescence through metabolic pathways. Future studies will aim to characterize the role for $\mathrm{HIC1}$ in T-cell quiescence and memory development.

Another observation was the increase in the frequency of IL-17A-producing $\mathrm{T}_{\mathrm{H}} 17$ cells in the intestine of $\mathrm{Hicl}^{\Delta T}$ mice. $\mathrm{T}_{\mathrm{H}} 17$ cells have been shown to have an important role in host defense to extracellular bacteria and fungi. ${ }^{50}$ However, they have also been described as pathogenic in multiple inflammatory diseases such as psoriasis and rheumatoid arthritis, and targeting IL-17A has proven to be an effective therapy. ${ }^{51-53}$ However, the role of IL-17A in inflammatory bowel disease is controversial. Initial studies using the T-cell transfer model of colitis provided the first evidence that IL-23-driven $\mathrm{T}_{\mathrm{H}} 17$ cells were pathogenic. ${ }^{54}$ Further, STAT3 was shown to be required to drive both colitis and systemic inflammation not only by modulating $\mathrm{T}_{\mathrm{H}} 17$-cell differentiation but also by promoting T-cell activation and survival. ${ }^{41}$ However, targeted therapies against IL-17A in Crohn's disease have been proven ineffective $^{55,56}$ and recent studies have shown that IL-17A is important for maintaining intestinal barrier integrity and has a protective role in regard to the development of colitis. ${ }^{57,58}$ Further, it is becoming more apparent that the $\mathrm{T}_{\mathrm{H}} 17$-cell lineage has a degree of heterogeneity with regards to pathogenicity. For example, $\mathrm{T}_{\mathrm{H}} 17$ cells differentiated in the presence of TGF $\beta$ are less pathogenic and produce higher levels of IL-10, whereas cells differentiated in the presence of IL-23 are more pathogenic and can produce IFN- $\gamma \cdot{ }^{59,60}$ In addition, $\mathrm{T}_{\mathrm{H}} 17$ cells have a degree of plasticity and fate-mapping studies have shown that "ex- $\mathrm{T}_{\mathrm{H}} 17$ " cells lose their ability to produce IL-17A altogether and exclusively produce IFN- $\gamma$ under certain conditions. ${ }^{61}$ As our studies show increased production of IL-17A from $\mathrm{T}_{\mathrm{H}} 17$ cells and a lack of pathogenicity in multiple mouse models of intestinal inflammation, we hypothesize that in the absence of $\mathrm{HIC} 1, \mathrm{~T}_{\mathrm{H}} 17$ cells are skewed to a more protective lineage and do not transition into pathogenic cells. Further, it has been shown that STAT3 can inhibit transcription of key genes from other $\mathrm{T}_{\mathrm{H}}$-cell lineages ${ }^{62}$ and therefore may provide $\mathrm{T}_{\mathrm{H}} 17$ lineage stability in the absence of HIC1. However, the precise molecular mechanism of how $\mathrm{HIC} 1$ regulates the pathogenicity of T cells remains to be fully elucidated.

In summary, we have identified the transcription factor $\mathrm{HIC1}$ as an RA-responsive cell-intrinsic regulator of T-cell function in the intestine. Through its interaction with STAT3,
HIC1 limits IL-17A production by $\mathrm{T}_{\mathrm{H}} 17$ cells and is required for the development of intestinal inflammation. Together, these results suggest that $\mathrm{HIC1}$ is an attractive therapeutic target for the treatment of inflammatory diseases of the intestine such as Crohn's disease and potentially other diseases associated with dysregulated $\mathrm{T}_{\mathrm{H}} 17$-cell responses.

\section{METHODS}

Ethics statement. Experiments were approved by the University of British Columbia Animal Care Committee (Protocol number A15-0196) and were in accordance with the Canadian Guidelines for Animal Research.

Mice. The generation of $\mathrm{Hicl}^{\text {Citrine }}$ mice has been described ${ }^{18}$ and the generation of $\mathrm{Hicl}^{f l / f l}$ mice will be described elsewhere (manuscript in preparation). Cd4-Cre mice were obtained from Taconic (Germantown, NY). Animals were maintained in a specific pathogen-free environment at the Biomedical Research Centre animal facility.

Diet studies. VAD (TD.09838) diet was purchased from Harlan Teklad Diets (Madison, WI). At day 14.5 of gestation, pregnant females were administered the VAD diet and maintained on diet until weaning of litter. Upon weaning, females were returned to standard chow, whereas weanlings were maintained on special diet until use.

Antibodies and flow cytometry. Absolute numbers of cells were determined via hemocytometer or with latex beads for LP samples. Intracellular cytokine staining was performed by stimulating cells with phorbol 12-myristate 13-acetate, ionomycin, and Brefeldin-A (Sigma, St. Louis, MO) for $4 \mathrm{~h}$ and fixing/permeabilizing cells using the eBioscience intracellular cytokine buffer kit. All antibody dilutions and cell staining were done with phosphate-buffered saline containing $2 \%$ fetal calf serum, $1 \mathrm{mM}$ ethylenediaminetetraacetic acid, and $0.05 \%$ sodium azide. Fixable Viability Dye eFluor 506 was purchased from eBioscience (San Diego, CA) to exclude dead cells from analyses. Prior to staining, samples were Fc-blocked with buffer containing antiCD16/32 (93, eBioscience) and 1\% rat serum to prevent non-specific antibody binding. Cells were stained with fluorescent conjugated antiCD11b (M1/70; in house), anti-CD4 (GK1.5), anti-CD8 (53-6.7), antiTCR $\beta$ (H57-597), anti-MHCII (I-A/I-E) (M5/114.15.2), anti-CD11c (N418), anti-F4/80 (BM8), anti-IL17a (17B7), anti-FOXP3 (FJK-16s), anti-B220 (RA3-6B2), anti-TCR $\gamma \delta$ (eBioGL3), anti-CD45 (30-F11), anti-CD45RB (C363.16A) anti- $\alpha 4 \beta 7$ (DATK32), anti-CCR9 (eBioCW-1.2), anti-IFN- $\gamma$ (XMG1.2), CD25 (PC61.5), IL-13 (eBio13A) purchased from eBioscience, anti-CD103 (M290), antiCD69 (H1.2F3), anti-CD62L (MEL-14), anti-CD44 (IM7), anti-CD64 (X54.5/7.1.1), anti- phosphorylated STAT3 (pY705) purchased from BD Biosciences (San Jose, CA). Data were acquired on an LSR II flow cytometer (BD Biosciences) and analyzed with FlowJo software (TreeStar, Ashland, OR).

RNA isolation and quantitative real-time PCR. Tissues were mechanically homogenized and RNA was extracted using the TRIzol method according to the manufacturer's instructions (ThermoFisher Scientific, Waltham, MA). cDNA was generated using High Capacity cDNA reverse transcription kits (ThermoFisher Scientific). Quantitative PCR was performed using SYBR FAST (Kapa Biosystems, Wilmington, MA) and SYBR green-optimized primer sets run on an ABI 7900 real-time PCR machine. Cycle threshold $\left(C_{T}\right)$ values were normalized relative to beta-actin $(A c t b)$ gene expression. The primers used were synthesized de novo:

Hic1:

forward 5'-AACCTGCTAAACCTGGACCAT- $3^{\prime}$

reverse $5^{\prime}$-CCACGAGGTCAGGGATCTG-3'

Il17a: 
forward 5'-AGCAGCGATCATCCCTCAAAG-3' reverse $5^{\prime}$-TCACAGAGGGATATCTATCAGGGTC-3' Ifng:

forward 5'- GGATGCATTCATGAGTATTGCC-3' reverse 5'-CCTTTTCCGCTTCCTGAGG-3'

Il13:

forward $5^{\prime}$-CCTGGCTCTTGCTTGCCTT- $3^{\prime}$ reverse $5^{\prime}$ - GGTCTTGTGTGATGTTGCTCA-3' Foxp3:

forward 5' - CCCAGGAAAGACAGCAACCTT-3' reverse $5^{\prime}$ - TTCTCACAACCAGGCCACTTG-3' Rorc:

forward $5^{\prime}$ - TCCACTACGGGGTTATCACCT- $3^{\prime}$ reverse $5^{\prime}$ - AGTAGGCCACATTACACTGCT-3' Socs3:

forward $5^{\prime}$ - TGCAAGGGGAATCTTCAAAC- $3^{\prime}$ reverse $5^{\prime}$ - TGGTTATTTCTTTTGCCAGC-3'

Irf4:

forward 5' - CCGACAGTGGTTGATCGACC-3' reverse 5' - CCTCACGATTGTAGTCCTGCTT-3' Ahr:

forward 5'- GCCCTTCCCGCAAGATGTTAT-3' reverse $5^{\prime}$ - GCTGACGCTGAGCCTAAGAAC-3' Il23r:

forward 5' - AACAACAGCTCGGATTTGGTAT-3' reverse $5^{\prime}$ - ATGACCAGGACATTCAGCAGT-3' Actb:

forward 5'-GGCTGTATTCCCCTCCATCG-3'

reverse $5^{\prime}$-CCAGTTGGTAACAATGCCATGT- $3^{\prime}$.

Cell culture. $\mathrm{CD}^{+} \mathrm{T}$ cells were isolated from spleen and LNs by negative selection using an EasySep Mouse $\mathrm{CD} 4{ }^{+} \mathrm{T}$ cell isolation kit (StemCell Technologies, Vancouver, BC). In total, $5 \times 10^{5} \mathrm{CD} 4^{+}$cells were cultured for up to 5 days in Dulbecco's Modified Eagle's mediumsupplemented with $10 \%$ heat-inactivated fetal bovine serum, $2 \mathrm{~mm}$ glutamine, $100 \mathrm{U} \mathrm{ml}^{-1}$ penicillin, $100 \mu \mathrm{g} \mathrm{ml}^{-1}$ streptomycin, $25 \mathrm{~mm}$ HEPES, and $5 \times 10^{-5} 2$-ME with $1 \mu \mathrm{g} \mathrm{ml}^{-1}$ plate bound anti-CD3 (145$2 \mathrm{C} 11)$ and anti-CD28 (37.51). CD $4^{+} \mathrm{T}$ cells were polarized under $\mathrm{T}_{\mathrm{H}} 17$ cell- $\left(20 \mathrm{ng} \mathrm{ml}^{-1} \mathrm{IL}-6,10 \mathrm{ng} \mathrm{ml}^{-1} \mathrm{IL}-23\right.$, TNF- $\alpha$, IL- $1 \beta, 1 \mathrm{ng} \mathrm{ml}^{-1}$ TGF- $\beta 1,10 \mu \mathrm{g} \mathrm{ml}^{-1}$, anti-IFN- $\gamma$ and anti-IL-4), $\mathrm{T}_{\mathrm{H}} 1$ cell- $\left(10 \mathrm{ng} \mathrm{ml}^{-1}\right.$ IL-2, IL-12, and $5 \mu \mathrm{g} \mathrm{ml}^{-1}$ anti-IL-4), $\mathrm{T}_{\mathrm{H}} 2$ cell- $\left(10 \mathrm{ng} \mathrm{ml}^{-1} \mathrm{IL}-2, \mathrm{IL}-4\right.$, and $5 \mu \mathrm{g} \mathrm{ml}^{-1}$ anti-IFN- $\gamma$ ) or induced $\mathrm{T}_{\text {reg }}$ cell- $\left(10 \mathrm{ng} \mathrm{ml}^{-1}\right.$ IL- 2 and TGF $\beta 1$ ) promoting conditions. In some cases, cells were plated as above in the presence of $10 \mathrm{~nm}$ RA (Sigma-Aldrich).

ELISA. IL-17A production was analyzed from supernatants taken on day 4 of $\mathrm{CD}^{+}{ }^{+} \mathrm{T}$ cell in vitro culture using commercially available antibody pairs (eBioscience).

Anti-CD3-induced intestinal inflammation. Mice were administered $30 \mu \mathrm{g}$ of anti-CD3 $\varepsilon$ antibody (145-2C11) in $400 \mu \mathrm{l}$ phosphate-buffered saline by intraperitoneal injection. Animals were monitored daily after injection and euthanized at $48 \mathrm{~h}$ post injection. At end point, sections of the distal ileum were fixed in $10 \%$ buffered formalin, embedded in paraffin, and stained with haematoxylin and eosin. Histological inflammations were blindly scored on a scale of 0 to 4 , where 0 represented a normal ileum and 4 represented severe inflammation. Specific aspects such as infiltrating immune cells, crypt length, epithelial erosion, and muscle thickness were taken into account.

T-cell transfer colitis. CD4 ${ }^{+}$cells were enriched from spleens and peripheral LNs of Hicl ${ }^{\text {flflf }}$ or Hicl ${ }^{\Delta T}$ mice with an EasySep Mouse $\mathrm{CD}^{+} \mathrm{T}$ cell isolation kit (StemCell Technologies) and stained with anti-CD4, anti-CD25, and anti-CD45RB. Naive $\mathrm{CD} 4{ }^{+} \mathrm{CD} 25^{-}$ $\mathrm{CD} 45 \mathrm{RB}^{\text {hi }}$ cells were purified by cell sorting. CD $4^{+} \mathrm{CD} 25^{-} \mathrm{CD} 45 \mathrm{RB}{ }^{\mathrm{hi}}$ naive $\mathrm{T}$ cells $\left(4 \times 10^{5}\right)$ were injected intraperitoneally into age-and sex-matched $\mathrm{Ragl}^{-/-}$mice, which were monitored for weight loss and killed 6 weeks after initiation of the experiment. At end point, proximal colon was fixed, embedded, and stained with haematoxylin and eosin. Histological inflammation was scored as above.

DSS-induced colitis. Mice were exposed to $3.5 \%$ DSS in their drinking water for 7 days before returning to regular drinking water for 1 final day. Mice were monitored for weight loss and killed on day 8 . At end point, proximal colon was fixed, embedded, and stained with haematoxylin and eosin. Histological inflammation was scored as above.

Isolation of intraepithelial and LPLs. Peyer's patches were removed from the small intestine, which was cut open longitudinally, briefly washed with ice-cold phosphate-buffered saline and cut into $1.5 \mathrm{~cm}$ pieces. Tissue was incubated in $2 \mathrm{~mm}$ ethylenediaminetetraacetic acid phosphate-buffered saline for $15 \mathrm{~min}$ at $37^{\circ} \mathrm{C}$ and extensively vortexed. Supernatants were collected and pelleted then re-suspended in 30\% Percoll solution and centrifuged for $10 \mathrm{~min}$ at $1200 \mathrm{rpm}$. The pellet was collected and used as intraepithelial leukocytes. Remaining tissue was digested with Collagenase/Dispase (Roche) $\left(0.5 \mathrm{mg} \mathrm{m}^{-1}\right)$ on a shaker at $250 \mathrm{rpm}, 37^{\circ} \mathrm{C}$, for $60 \mathrm{~min}$, extensively vortexed and filtered through a $70 \mu \mathrm{m}$ cell strainer. The flow-through cell suspension was centrifuged at $1500 \mathrm{rpm}$ for $5 \mathrm{~min}$. The cell pellet was re-suspend in $30 \%$ Percoll solution and centrifuged for $10 \mathrm{~min}$ at $1200 \mathrm{rpm}$. The pellet was collected and used as LPLs.

Cell lysis, immunoprecipitation, and immunoblotting. Cells were lysed and immunoprecipitation carried out using antibodies against STAT3 (C-20; Santa Cruz, Dallas, TX) and FLAG (M2; Sigma). Immunoblotting was carried out using antibodies against STAT3, HIC1 (H-123; Santa Cruz) and GAPDH (GA1R; in house).

Chromatin immunoprecipitiation. Naive $\mathrm{CD} 4{ }^{+} \mathrm{T}$ cells were activated and $\mathrm{T}_{\mathrm{H}} 17$ polarized for 3 days, followed by cross-linking for $8 \mathrm{~min}$ with $1 \%$ (vol/vol) formaldehyde. Cells were collected, lysed, and sonicated. After being precleared with protein A agarose beads (EMD Millipore, Billerica, MA), cell lysates were immunoprecipitated overnight at $4{ }^{\circ} \mathrm{C}$ with anti-STAT3 (C-20, Santa Cruz) or normal rabbit IgG (Cell Signaling, Danvers, MA). After washing and elution, cross-links were reversed for $4 \mathrm{~h}$ at $65^{\circ} \mathrm{C}$. Eluted DNA was purified and samples were analyzed by quantitative real time PCR on a 7900 Real-Time PCR system. Primer sets used for analysis are: $I l 17 a$ promoter forward $5^{\prime}$ - CACCTCACACGAGGCACAAG $-3^{\prime}$ and reverse $5^{\prime}$-ATGTTT GCGCGTCCTGATC - $3^{\prime}$; Il5 promoter forward $5^{\prime}$-AAGTCTAGCT ACCGCCAATA- $3^{\prime}$ and reverse $5^{\prime}$ - AGCAAAGGTGAGTTCAATC $\mathrm{T}-3^{\prime}$. Each Ct value was normalized to the corresponding input value.

Retroviral transduction. Platinum E cells were transiently transfected using the calcium phosphate method with MigR1 expression plasmids encoding GFP alone or FLAG-HIC1. Viral supernatants were collected after $48 \mathrm{~h}$, supplemented with $8 \mu \mathrm{g} \mathrm{ml}^{-1}$ polybrene (EMD Millipore) and added to $T$ cells that had been activated under $\mathrm{T}_{\mathrm{H}} 17$ cell-polarizing conditions for $48 \mathrm{~h}$. T cells $\left(2 \times 10^{6}\right)$ were incubated in 24 -well plates with $1 \mathrm{ml}$ viral supernatants. After $24 \mathrm{~h}$, viral supernatant was replaced with conditioned culture medium and cells were cultured under $\mathrm{T}_{\mathrm{H}} 17$ cell-polarizing conditions for an additional 3 days.

Statistics. Data are presented as mean \pm s.e.m. Statistical significance was determined by a two-tailed Student's $t$-test using GraphPad Prism 5 software. Results were considered statistically significant with $P<0.05$.

SUPPLEMENTARY MATERIAL is linked to the online version of the paper at http://www.nature.com/mi

\section{ACKNOWLEDGMENTS}

We thank C. Hunter, K. Jacobson, and S. Gerondakis for advice on the manuscript. We thank R. Dhesi, L. Rollins (BRC core), A. Johnson (UBCFlow), M. Williams (UBC AbLab), T. Murakami (BRC Genotyping), I. Barta (BRC Histology), and all members of BRC mouse facility for excellent technical assistance. This work was supported by the Canadian Institutes of Health Research's (ClHR) Canadian Epigenetics, Environment and Health Research 
Consortium (grant 128090 to C. Zaph) and operating grants (MOP-89773 and MOP-106623 to C. Zaph) and Australian National Health and Medical Research Council (NHMRC) project grants (APP1104433 and APP1104466 to C. Zaph). F. Antignano is the recipient of a ClHR/Canadian Association of Gastroenterology/Crohn's and Colitis Foundation of Canada postdoctoral fellowship. C. Zaph is a Michael Smith Foundation for Health Research Career Investigator and a veski innovation fellow.

\section{AUTHOR CONTRIBUTIONS}

K.B., F.A., A.C., M.B., S.S. and C.Z. designed and performed the experiments. T.M.U. and V.K. provided assistance and contributed reagents and materials. K.B. and C.Z. wrote the manuscript.

\section{DISCLOSURE}

The authors declared no conflict of interest.

Official journal of the Society for Mucosal Immunology

\section{REFERENCES}

1. Scott, C.L., Aumeunier, A.M. \& Mowat, A.M. Intestinal CD103 ${ }^{+}$dendritic cells: master regulators of tolerance?. Trends Immunol. 32, 412-419 (2011).

2. Smith, P., Smythies, L., Shen, R., Greenwell-Wild, T., Gliozzi, M. \& Wahl, S. Intestinal macrophages and response to microbial encroachment. Mucosal immunol. 4, 31-42 (2011).

3. Bain, C.C. \& Mowat, A.M. Macrophages in intestinal homeostasis and inflammation. Immunological Reviews 260, 102-117 (2014).

4. Littman, D.R. \& Rudensky, A.Y. Th17 and regulatory Tcells in mediating and restraining inflammation. Cell 140, 845-858 (2010).

5. Cheroutre, H., Lambolez, F. \& Mucida, D. The light and dark sides of intestinal intraepithelial lymphocytes. Nat. Rev. Immunol. 11, 445-456 (2011).

6. Suzuki, K., Ha, S., Tsuji, M. \& Fagarasan, S. Intestinal IgA synthesis: a primitive form of adaptive immunity that regulates microbial communities in the gut. Semin. Immunol. 19, 127-135 (2007).

7. Kelly, K.F. \& Daniel, J.M. POZ for effect-POZ-ZF transcription factors in cancer and development. Trends Cell Biol. 16, 578-587 (2006).

8. Lee, S.-U. \& Maeda, T. POK/ZBTB proteins: an emerging family of proteins that regulate lymphoid development and function. Immunol. Rev. 247, 107-119 (2012).

9. Allman, D. et al. BCL-6 expression during B-cell activation. Blood 87 , 5257-5268 (1996)

10. Nurieva, R.I. et al. Bcl6 mediates the development of T follicular helper cells. Science 325, 1001-1005 (2009).

11. Savage, A.K. et al. The transcription factor PLZF directs the effector program of the NKT cell lineage. Immunity 29, 391-403 (2008).

12. Constantinides, M.G., McDonald, B.D., Verhoef, P.A. \& Bendelac, A. A committed precursor to innate lymphoid cells. Nature 508, 397-401 (2014).

13. Muroi, S. et al. Cascading suppression of transcriptional silencers by ThPOK seals helper T cell fate. Nat. Immunol. 9, 1113-1121 (2008).

14. Wang, L. et al. Distinct functions for the transcription factors GATA-3 and ThPOK during intrathymic differentiation of CD4(+) T cells. Nat. Immunol. 9, 1122-1130 (2008).

15. Chen, W.Y. et al. Heterozygous disruption of Hic1 predisposes mice to a gender-dependent spectrum of malignant tumors. Nat. Genet. 33 , 197-202 (2003).

16. Wales, M.M. et al. p53 activates expression of HIC-1, a new candidate tumour suppressor gene on 17p13.3. Nat. Med. 1, 570-577 (1995).

17. Chen, W.Y., Wang, D.H., Yen, R.C., Luo, J., Gu, W. \& Baylin, S.B. Tumor suppressor HIC1 directly regulates SIRT1 to modulate p53-dependent DNA-damage responses. Cell 123, 437-448 (2005).

18. Pospichalova, V. et al. Generation of two modified mouse alleles of the Hic1 tumor suppressor gene. Genesis 49, 142-151 (2011).

19. Matloubian, M. et al. Lymphocyte egress from thymus and peripheral lymphoid organs is dependent on S1P receptor 1. Nature 427, 355-360 (2004).
20. Skon, C.N., Lee, J.-Y., Anderson, K.G., Masopust, D., Hogquist, K.A. \& Jameson, S.C. Transcriptional downregulation of S1 pr1 is required for the establishment of resident memory $\mathrm{CD}^{+}{ }^{+} \mathrm{T}$ cells. Nat. Immunol. 14, 1285-1293 (2013).

21. Schön, M.P. et al. Mucosal T lymphocyte numbers are selectively reduced in integrin alpha $E$ (CD103)-deficient mice. J. Immunol. 162, 6641-6649 (1999).

22. Brown, C.C. et al. Retinoic acid is essential for Th1 cell lineage stability and prevents transition to a Th17 cell program. Immunity 42, 499-511 (2015).

23. Hall, J.A. et al. Essential role for retinoic acid in the promotion of CD4(+) $\mathrm{T}$ cell effector responses via retinoic acid receptor alpha. Immunity 34 , 435-447 (2011).

24. Iwata, M., Hirakiyama, A., Eshima, Y., Kagechika, H., Kato, C. \& Song, S.-Y. Retinoic acid imprints gut-homing specificity on $\mathrm{T}$ cells. Immunity 21, 527-538 (2004).

25. Johansson-Lindbom, B. et al. Functional specialization of gut CD103+ dendritic cells in the regulation of tissue-selective T cell homing. J. Exp. Med. 202, 1063-1073 (2005).

26. Hill, J.A. et al. Retinoic acid enhances Foxp3 induction indirectly by relieving inhibition from CD4 + CD44hi Cells. Immunity 29, 758-770 (2008).

27. Mucida, D. et al. Reciprocal $\mathrm{TH} 17$ and regulatory $\mathrm{T}$ cell differentiation mediated by retinoic acid. Science 317, 256-260 (2007).

28. Mucida, D. et al. Retinoic acid can directly promote TGF-beta-mediated Foxp3(+) Treg cell conversion of naive T cells. Immunity 30, 471-472 (2009). author reply 472-3.

29. Schambach, F., Schupp, M., Lazar, M.A. \& Reiner, S.L. Activation of retinoic acid receptor-alpha favours regulatory $T$ cell induction at the expense of IL-17-secreting Thelper cell differentiation. Eur. J. Immunol. 37, 2396-2399 (2007).

30. Esplugues, E. et al. Control of $\mathrm{TH} 17$ cells occurs in the small intestine. Nature 475, 514-518 (2011).

31. Merger, M. et al. Defining the roles of perforin, Fas/FasL, and tumour necrosis factor in Tcell induced mucosal damage in the mouse intestine. Gut 51, 155-163 (2002).

32. Rutz, S. et al. Deubiquitinase DUBA is a post-translational brake on interleukin-17 production in T cells. Nature 518, 417-421 (2015).

33. Powrie, F., Leach, M.W., Mauze, S., Caddle, L.B. \& Coffman, R.L. Phenotypically distinct subsets of $\mathrm{CD} 4^{+} \mathrm{T}$ cells induce or protect from chronic intestinal inflammation in C. B-17 scid mice. Int. Immunol. 5 , 1461-1471 (1993).

34. Chassaing, B., Aitken, J.D., Malleshappa, M. \& Vijay-Kumar, M. Dextran sulfate sodium (DSS)-induced colitis in mice. Curr. Protoc. Immunol. 104, Unit 15.25 (2014).

35. Dieleman, L.A., Ridwan, B.U., Tennyson, G.S., Beagley, K.W., Bucy, R.P. \& Elson, C.O. Dextran sulfate sodium-induced colitis occurs in severe combined immunodeficient mice. Gastroenterology 107, 1643-1652 (1994).

36. Boulay, G. et al. Hypermethylated in cancer 1 (HIC1) recruits polycomb repressive complex 2 (PRC2) to a subset of its target genes through interaction with human polycomb-like (hPCL) proteins. J. Biol. Chem. 287, 10509-10524 (2012).

37. Van Rechem, C., Boulay, G., Pinte, S., Stankovic-Valentin, N., Guérardel, C. \& Leprince, D. Differential regulation of HIC1 target genes by CtBP and NuRD, via an acetylation/SUMOylation switch, in quiescent versus proliferating cells. Mol. Cell Biol. 30, 4045-4059 (2010).

38. Hu, B. et al. HIC1 attenuates invasion and metastasis by inhibiting the IL-6/ STAT3 signalling pathway in human pancreatic cancer. Cancer Lett. 376, 387-398 (2016)

39. Lin, Y.-M., Wang, C.-M., Jeng, J.-C., Leprince, D. \& Shih, H.-M. HIC1 interacts with and modulates the activity of STAT3. Cell Cycle 12, 2266-2276 (2013).

40. Valenta, T., Lukas, J., Doubravska, L., Fafilek, B. \& Korinek, V. HIC1 attenuates Wnt signaling by recruitment of TCF- 4 and beta-catenin to the nuclear bodies. EMBO J. 25, 2326-2337 (2006).

41. Durant, L. et al. Diverse targets of the transcription factor STAT3 contribute to $\mathrm{T}$ cell pathogenicity and homeostasis. Immunity $\mathbf{3 2}$, 605-615 (2010).

42. Kang, S.G., Park, J., Cho, J.Y., Ulrich, B. \& Kim, C.H. Complementary roles of retinoic acid and TGF- $\beta 1$ in coordinated expression of mucosal integrins by T cells. Mucosal Immunol. 4, 66-82 (2011). 
43. Lalevée, S. et al. Genome-wide in silico identification of new conserved and functional retinoic acid receptor response elements (direct repeats separated by 5 bp). J. Biol. Chem. 286, 33322-33334 (2011).

44. Dehennaut, V., Loison, I., Pinte, S. \& Leprince, D. Molecular dissection of the interaction between HIC1 and SIRT1. Biochem. Biophys. Res. Commun. 421, 384-388 (2012).

45. Rood, B.R. \& Leprince, D. Deciphering HIC1 control pathways to reveal new avenues in cancer therapeutics. Expert Opin. Ther. Targets 17, 811-827 (2013).

46. Li, P. et al. Interferon gamma (IFN- $\gamma$ ) disrupts energy expenditure and metabolic homeostasis by suppressing SIRT1 transcription. Nucleic Acids Res. 40, 1609-1620 (2012).

47. Gerhart-Hines, Z. et al. Metabolic control of muscle mitochondrial function and fatty acid oxidation through SIRT1/PGC-1alpha. EMBO J. 26, 1913-1923 (2007).

48. Pearce, E.L. et al. Enhancing CD8 T-cell memory by modulating fatty acid metabolism. Nature 460, 103-107 (2009).

49. van der Windt, G.J.W. \& Pearce, E.L. Metabolic switching and fuel choice during T-cell differentiation and memory development. Immunol. Rev. 249, 27-42 (2012).

50. Annunziato, F., Romagnani, C. \& Romagnani, S. The 3 major types of innate and adaptive cell-mediated effector immunity. J. Allergy Clin. Immunol. 135, 626-635 (2015).

51. Genovese, M.C. et al. LY2439821, a humanized anti-interleukin-17 monoclonal antibody, in the treatment of patients with rheumatoid arthritis: a phase I randomized, double-blind, placebo-controlled, proof-of-concept study. Arthritis Rheum. 62, 929-939 (2010).

52. Leonardi, C. et al. Anti-interleukin-17 monoclonal antibody ixekizumab in chronic plaque psoriasis. N. Engl. J. Med. 366, 1190-1199 (2012).

53. Papp, K.A. et al. Brodalumab, an anti-interleukin-17-receptor antibody for psoriasis. N. Engl. J. Med. 366, 1181-1189 (2012).

54. Ahern, P.P. et al. Interleukin-23 drives intestinal inflammation through direct activity on T cells. Immunity 33, 279-288 (2010).

55. Hueber, W. etal. Secukinumab, a human anti-IL-17A monoclonal antibody, for moderate to severe Crohn's disease: unexpected results of a randomised, double-blind placebo-controlled trial. Gut 61, 1693-1700 (2012).

56. Targan, S.R. et al. Mo2083 a randomized, double-blind, placebocontrolled study to evaluate the safety, tolerability, and efficacy of AMG 827 in subjects with moderate to severe Crohn's disease. Gastroenterology 143, e26 (2012).

57. Lee, J.S. et al. Interleukin-23-independent IL-17 production regulates intestinal epithelial permeability. Immunity 43, 727-738 (2015).

58. Maxwell, J.R. et al. Differential roles for interleukin-23 and interleukin-17 in intestinal immunoregulation. Immunity 43, 739-750 (2015).

59. Lee, Y. et al. Induction and molecular signature of pathogenic $\mathrm{TH} 17$ cells. Nat. Immunol. 13, 991-999 (2012).

60. McGeachy, M.J. et al. TGF- $\beta$ and IL-6 drive the production of IL-17 and $\mathrm{IL}-10$ by $\mathrm{T}$ cells and restrain $\mathrm{TH}-17$ cell-mediated pathology. Nat. Immunol. 8, 1390-1397 (2007).

61. Hirota, K. et al. Fate mapping of IL-17-producing T cells in inflammatory responses. Nat. Immunol. 12, 255-263 (2011).

62. Wan, C.-K. et al. Opposing roles of STAT1 and STAT3 in IL-21 function in CD4 ${ }^{+}$T cells. Proc. Natl. Acad. Sci. 112, 9394-9399 (2015).

(c) (1) This work is licensed under a Creative Commons Attribution 4.0 International License. Theimages or other third party material in thisarticleareincluded in thearticle's Creative Commons license, unless indicated otherwise in the credit line; if the material is not included under the Creative Commons license, users will need to obtain permission from the license holder to reproduce the material. To view a copy of this license, visit http://creativecommons.org/licenses/by/4.0/

(C) The Author(s) 2017 